\title{
Respiratory Syncytial Virus Infections during an Epidemic Period in Salvador, Brazil. Viral Antigenic Group Analysis and Description of Clinical and Epidemiological Aspects
}

\author{
Fernanda Edna Araújo Moura/ ${ }^{+}$, Leonardo Carletto Borges, Silvana Augusta Rodrigues \\ Portes, Eduardo Antônio Gonçalves Ramos, Marilda Mendonça Siqueira*
}

\author{
Laboratório de Patologia e Doenças Virais, Centro de Pesquisas Gonçalo Moniz-Fiocruz, Rua Valdemar Falcão 121, 40295-001 \\ Salvador, BA, Brasil *Laboratório de Vírus Respiratórios, Instituto Oswaldo Cruz-Fiocruz, Rio de Janeiro, RJ, Brasil
}

Acute respiratory infections (ARI) caused by respiratory syncytial virus (RSV) were studied in 482 children from Salvador, BA, Brazil, over a period of 12 months. The epidemic period of RSV infections in Salvador occurred from February (summer) to August (winter), with peaks in May, June, and July. The grouping characteristics of 84 RSV present in nasopharyngeal secretions of children seen at a reference university hospital were analyzed. RSV represented $17.4 \%$ of all cases and $54.5 \%$ of the positive samples. Sixty-four RSV strains were assigned to group A and 14 to group B. Both groups circulated in the five months of the epidemic period studied. Infections by both groups of RSV were more frequent in children up to one year of age. The incidence of RSV ARI was slightly more frequent in males, although group B had more infected females.

Key words: respiratory syncytial virus (RSV) - acute respiratory infection - RSV groups A and B - child - Salvador - Brazil

Respiratory syncytial virus (RSV) is the most important cause of viral lower respiratory tract illness (LRTI) in children and vulnerable adults, such as the elderly and immunocompromised individuals (Collins et al. 1996).

The existence of two major antigenic groups of RSV, groups A and B, has been clearly established (Anderson et al. 1985, Mufson et al. 1985). There is also antigenic and genetic variability within the individual groups of RSV (Sullender 2000). The ability to discriminate RSV groups is of immediate relevance for analysis of epidemiology and immunology of infection and reinfection with RSV and for providing crucial information for vaccine development efforts.

RSV has a worldwide distribution, with outbreaks occurring yearly and has an unusually predictable and regular pattern. In temperate climates, RSV causes annual epidemics during the winter months (Collins et al. 1996), while epidemiological data from tropical regions have shown an association between RSV outbreaks and rainy seasons (Hierholzer et al. 1994, Weber et al. 1998a, Cane et al. 1999, Loscertales et al 2002).

Several studies have shown different patterns of circulation of RSV subgroups: those in which both groups are detected, but one of them is predominant (more frequently group A), those in which both groups cocirculate at a similar frequency, and those in which only viruses from one group are detected (Roca et al. 2001, Kong et al. 2001).

\footnotetext{
${ }^{+}$Corresponding author's present address: Departamento de Patologia e Medicina Legal, Universidade Federal do Ceará, Rua Monsenhor Furtado s/no ${ }^{\circ}$, 60441-750 Fortaleza,CE, Brasil. Fax:+55-85-272.4755. E-mail: hugom@daterranet.com.br Received 26 March 2003

Accepted 4 August 2003
}

Brazil is a very large country with five geographic regions, each one with unique climate characteristics. Brazilian data about the pattern of RSV infection and circulation of the RSV groups have been obtained mostly from cities in the Southeastern, Southern and Northern regions (Nascimento et al. 1991, Siqueira et al. 1991, Mello \& Silva 1992, Sutmoller et al. 1995, Cintra et al. 2001, Vieira et al. 2001, Straliotto et al. 2001, Checon et al 2002).

The aim of this study was to provide the first information about circulation of RSV groups and epidemiological aspects of RSV infections in infants and young children admitted to the emergency room and pediatric ward of one hospital in a Northeastern Brazilian city.

\section{MATERIALS AND METHODS}

Study area - Salvador, capital of the state of Bahia, is a city in Northeast Brazil with 2.5 million inhabitants at sea level, $13^{\circ} \mathrm{C}$ south of the equator. The climate is tropical with high relative humidity $(>70 \%)$, rainfall throughout the year with a peak from April to July, and drier months in December and January. During this study the temperature varied between $19-35^{\circ} \mathrm{C}$.

Target population - Children under five years of age with acute respiratory infections (ARI) within seven days of onset, attended in the emergency room and on the pediatric wards of the Pediatric Center Professor Hosannah de Oliveira (PCPHO) of the Federal University of Bahia (UFBA), Salvador, BA, Brazil. The PCPHO provides care to low-income children who live in Salvador city. The study period started on January 1st and ended on December 30th 1998. At the time of examination, patient history, socioeconomic background, clinical signs, and diagnosis were recorded on a standard form.

Case definition - Patients selected for this study had one or more of the following symptoms: cough, coryza, sore throat, earache, breathing difficulty, stridor, and/or 
wheezing. LRTI was characterized by the presence of dyspnea (respiratory rate $>50$ ), chest retractions, wheezing, rales, stridor or cyanosis or when a clinical diagnosis of LRTI was made by a physician. Upper respiratory tract infection was classified as cough, coryza, sore throat, and/or earache in the absence of the signs cited for LRTI.

Virological studies - Nasopharyngeal secretions (NPS) were obtained by suction through a nasal catheter with a specimen trap. All specimens were transported to the laboratory at $4^{\circ} \mathrm{C}$ within $2 \mathrm{~h}$ of collection.

Viral isolation - An aliquot of about $0.5 \mathrm{ml}$ of NPS was processed and placed in tubes containing $2 \mathrm{ml}$ of phosphate-buffered saline solution and $0.5 \%$ gelatin for isolation of HEp-2 cells in fresh monolayers, as described previously (Siqueira et al. 1986).

Indirect immunofluorescence assay (IFA) - All samples were tested by indirect immunofluorescence for antigen detection of RSV, adenovirus, influenza, and parainfluenza virus (Respiratory Viruses Panel I Viral Screening \& Identification Kit) according to manufacturer instructions (Chemicon Light Diagnostics, Catalog nr 3105).

Typing of RSV by IFA - Slides from RSV-positive specimens by IFA or cell culture were used for grouping characterization by IFA with MAbs specific for group A (92-11c) and group B (102-10b) (kindly supplied by Dr Larry Anderson, CDC/Atlanta, US).

Ethical guidelines - The present study was aproved by the Ethics Committees of Centro de Pesquisas Gonçalo Moniz-Fiocruz, and PCPHO. Informed consent was obtained from parents or legal guardians of the participants.

Statistical analysis - Data were analyzed statistically by the Chi-square test for categorical variables.

\section{RESULTS}

A total of 482 children with ARI attended in the emergency room $(n=360)$ and on the pediatric ward $(n=$ 122) of PCPHO were included in the study. Eighty-four patients were defined as RSV-infected patients, with 81 samples being positive by IFA and 30 positive by cell culture. Both tests were positive in 27 cases. Three samples were positive only in cell culture.

The RSV epidemic period lasted from Febuary to August, with a peak of occurrence during May, June, and July when $63 \%$ of all cases occurred. Both RSV groups circulated simultanously over a period of five months
(Febuary, March, May, June, July), while in two other months (April, August) only subgroup A was detected. Among 84 RSV analyzed, 64 reacted with a MAb specific for group A (76.1\%) and 14 with a MAb specific for group B. Four specimens did not react with either of the two MAbs and two reacted with both. The distribution of cases of ARI by antigenic groups of RSV during the study period is shown in the Figure.

Table I lists the number of RSV in each group and distribution by patient sex and site of attendance. Although the sex ratio among the RSV cases detected at PHOPC was nearly 1:1, there was a slight but not significant preponderance of males among children infected with subgoup A RSV (57.8\%), and of females among those infected with subgroup B (64.3\%).

The age of the children included in the study ranged from 3 days to 4.9 years, while in positive cases it ranged from 12 days to 3 years. Median age was 8.9 months. Table II shows the distribution of RSV groups by age. Acute respiratory infections due to both groups of RSV were more frequent in children in the first year of life $(76.2 \%)$.

The distribution of clinical cases between antigenic groups of RSV is shown in Table III. LTRI represented $56 \%(47 / 84)$ of the cases and upper respiratory tract infections (URTI) represented 44\% (37/84). Among the children with LTRI, the clinical diagnoses at admission were pneumonia (17 cases), bronchiolitis (13 cases), pneumonia with wheezing (12 cases), and wheezing (5

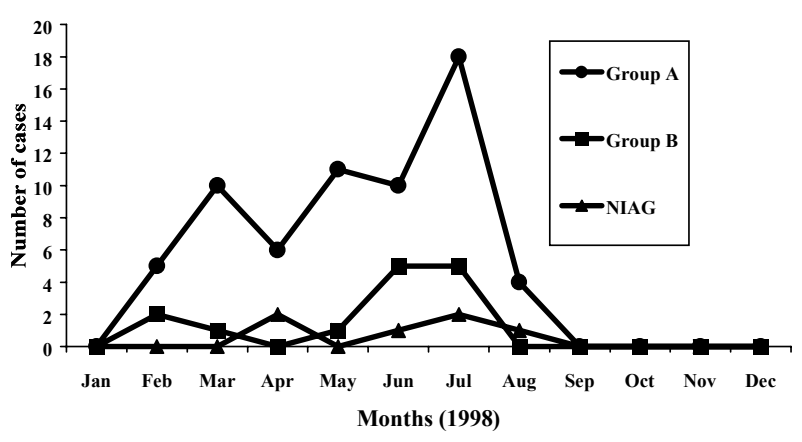

Monthly distribution of acute respiratory infections by antigenic groups of respiratory syncytial virus from January to December 1998 in children attended at the Pediatric Center Professor Hosannah de Oliveira; NIAG: not identified antigenic group

TABLE I

Distribution of antigenic groups of respiratory syncytial virus by sex and place of patient care

\begin{tabular}{lccr}
\hline Characteristics & $\begin{array}{c}\text { Group A } \\
\mathrm{n}(\%)\end{array}$ & $\begin{array}{c}\text { Group B } \\
\mathrm{n}(\%)\end{array}$ & $\begin{array}{c}\text { NIAG } \\
\mathrm{n}(\%)\end{array}$ \\
\hline $\begin{array}{l}\text { Sex } \\
\text { Male/female }\end{array}$ & $37(57.8) / 27(42.2)$ & $5(35.7) / 9(64.3)$ & $5(83.3) / 1(16.7)$ \\
$\begin{array}{l}\text { Place of collection } \\
\text { Emergency/ward }\end{array}$ & $37(57.8) / 27(42.2)$ & $12(85.7) / 2(14.3)$ & $5(83.3) / 1(16.7)$ \\
\hline Total & $64(76.2 \%)$ & $14(16.7)$ & $6(7.1)$ \\
\hline
\end{tabular}

NIAG: not identified antigenic group 
TABLE II

Acute respiratory infections due to different antigenic groups of respiratory syncytial virus according to patient age

\begin{tabular}{ccccr}
\hline $\begin{array}{c}\text { Age/antigenic group } \\
(\text { months) }\end{array}$ & $\begin{array}{c}\text { Group A } \\
\text { n (\%) }\end{array}$ & $\begin{array}{c}\text { Group B } \\
\text { ( }(\%)\end{array}$ & $\begin{array}{c}\text { NIAG } \\
\text { n }(\%)\end{array}$ & $\begin{array}{c}\text { Total } \\
\text { n (\%) }\end{array}$ \\
\hline $0-6$ & $30(79)$ & $5(13.1)$ & $3(7.9)$ & $1(3.8)$ \\
$7-12$ & $20(77)$ & $5(19.2)$ & $2(20)$ & $26(45.2)$ \\
$13-18$ & $6(60)$ & $2(20)$ & 0 & $10(11.9)$ \\
$19-24$ & $6(85.7)$ & $1(14.3)$ & 0 & $7(8.4)$ \\
$>24$ & $2(66.7)$ & $1(23.3)$ & $6(7.1)$ & $3(3.6)$ \\
\hline Total & $64(76.2)$ & $14(16.7)$ & & $84(100)$ \\
\hline
\end{tabular}

NIAG: not identified antigenic group

TABLE III

Distribution of clinical syndromes of acute respiratory infections due to antigenic groups of respiratory syncytial virus

\begin{tabular}{lcccc}
\hline $\begin{array}{l}\text { Clinical } \\
\text { syndrome }\end{array}$ & $\begin{array}{c}\text { Group A } \\
\mathrm{n}(\%)\end{array}$ & $\begin{array}{c}\text { Group B } \\
\mathrm{n}(\%)\end{array}$ & $\begin{array}{c}\text { NIAG } \\
\mathrm{n}(\%)\end{array}$ & $\begin{array}{c}\text { Total } \\
\mathrm{n}(\%)\end{array}$ \\
\hline URTI & $27(42.2)$ & $6(42.9)$ & $4(66.7)$ & $37(44)$ \\
LRTI & $37(57.8)$ & $8(57.1)$ & $2(33.3)$ & $47(56)$ \\
\hline Total & $64(76.2)$ & $14(16.7)$ & $6(7.1)$ & $84(100)$
\end{tabular}

NIAG: not identified antigenic group; LRTI: lower tract respiratory infection; URTI: upper respiratory tract infection

cases). LRTI was similarly distributed in both RSV groups. Cases of URTI by RSV were significantly more frequent in children attended in the emergency room $(p=0.001 \leq$ 0.05 ), while cases of LRTI were significantly more frequent in children attended on a ward $(p=0.001 \leq 0.05)$. Table IV shows the distribution of clinical syndromes due to groups A and B by different age groups. URTI and LRTI caused by group A were significantly more frequent among children up to 1 year of age $(p=0.025 \leq 0.05)$.

\section{DISCUSSION}

Studies from some Brazilian cities have shown a diversified seasonal pattern for RSV, probably related to the wide diversity of climate in our country. The RSV epidemic period in Salvador lasted seven months, with a peak of occurrence from May to July coinciding with the rainy season. The correlation between the peak of RSV cases and the rainy season observed in this study has been reported in some other studies from regions with a tropical climate. This correlation was also reported in a study from Belém, a Northern Brazilian city with equatorial climate (Mello \& Silva 1992). In studies from the cities of Rio de Janeiro and São Paulo, both located in Southeast Brazil, with a subtropical climate, the RSV outbreaks began in late March or early April, peaking in May and lasting five months (Nascimento et al. 1991, Vieira et al. 2001). The peak of RSV infections in these cities cannot be associated with the rainy seasons, which lasts from January through March and from September through November, nor with the coldest months (June, July, August). Epidemic outbreaks of RSV in South Brazil showed a temperature-dependent pattern and no association with rainfall, peaking in July or August, the coldest months of the year (Straliotto et al. 2001). This pattern of RSV outbreaks is similar to that observed in Southern South America countries such as Chile, Uruguay and Argentina (Russi et al. 1989, Avendaño et al. 1991, Imaz et al. 2000).

In 1998, we identified the simultaneous circulation of both RSV groups in Salvador city, with group A predominating over group B. A similar pattern of circulation of RSV groups in the same year was observed in cities in Southeast (Silva RECF 1999, pers. commun.) and South Brazil (Straliotto et al. 2001). Previous reports have shown that although RSV group A strains are, on average, three times more frequent than group B strains, there are outbreaks with similar incidence rates of groups A and B and others with a large predominance of group B, such as those observed in Rio de Janeiro and Porto Alegre cities in 1987 (Siqueira et al. 1991, Straliotto et al. 2001).

TABLE IV

Distribution of cases of acute respiratory infections caused by antigenic groups of respiratory syncytial virus according to age group and clinical syndrome

\begin{tabular}{|c|c|c|c|c|c|c|}
\hline \multirow{2}{*}{$\begin{array}{l}\text { Antigenic group } \\
\text { Age/syndromes } \\
\text { (months) }\end{array}$} & \multicolumn{2}{|c|}{ Group A } & \multicolumn{2}{|c|}{ Group B } & \multicolumn{2}{|c|}{ NIAG } \\
\hline & $\begin{array}{l}\text { LRTI } \\
\text { n (\%) }\end{array}$ & $\begin{array}{c}\text { URTI } \\
\text { n (\%) }\end{array}$ & $\begin{array}{l}\text { LRTI } \\
\text { n }(\%)\end{array}$ & $\begin{array}{l}\text { URTI } \\
\text { n }(\%)\end{array}$ & $\begin{array}{l}\text { LRTI } \\
\text { n }(\%)\end{array}$ & $\begin{array}{l}\text { URTI } \\
\text { n (\%) }\end{array}$ \\
\hline $0-12$ & $32(86.5)$ & $18(66.7)$ & $5(62.5)$ & $5(83.3)$ & $3(100)$ & $1(33.3)$ \\
\hline $13-24$ & $4(10.8)$ & 8 (29.6) & $3(29.6)$ & 0 & 0 & $2(66.7)$ \\
\hline$>24$ & $1(2.7)$ & $1(3.7)$ & 0 & 1(16.7) & 0 & 0 \\
\hline Total & $37(57.8)$ & $27(42.2)$ & $8(57.2)$ & $6(42.8)$ & $3(50)$ & $3(50)$ \\
\hline
\end{tabular}

NIAG: not identified antigenic group; LRTI: lower tract respiratory infection; URTI: upper respiratory tract infection 
Six RSV strains from Salvador were not grouped. The occurrence of intermediate strains or a mixture of strains from dual infections has been suggested in some studies by similar findings (Hendry et al. 1986, Russi et al. 1989, Siqueira et al. 1991). The utilization of different MAb panels and of other methodologies such as molecular analysis may have contributed to the detection of these intermediate strains.

Group A RSV predominated at the two sites of attendance and only two cases of group B infections occurred in hospitalized children. The evolution of all cases of RSV infections in children attended on PCPHO wards was favorable, similar to that observed among 100 hospitalized children followed in a study from São Paulo city (Vieira et al. 2001).

In agreement with literature data (Parrot et al. 1973, Glezen et al. 1981, Weber et al. 1998b, Loscertales et al. 2002), RSV infections by both groups in Salvador were more frequent in children during their first year of life and mostly during the first six months. In our study, RSV infections in children younger than one month occurred in two hospitalized children with pneumonia, and both RSV belonged to group A. The frequency of RSV infections decreased with increasing patient age. In this study only three children above two years of age had RSV infection.

Both RSV groups caused more LRTI than URTI among children attended at PCPHO. The bronchiolitis to pneumonia ratio $(1: 2.2)$ observed by us was similar to the one described in other developing country (Loscertales et al. 2002) and opposite to data from developed countries. LRTI infections due RSV (group A and B) were more frequent in children in their first year of life. Almost $60 \%$ of cases of LRTI due to RSV were diagnosed in children attended on the pediatric ward. Of 28 cases of LRTI by RSV among children attended on the pediatric ward, $89 \%$ were due to RSV group A. The frequency of LRTI by RSV decreases gradually during the preschool years, and this was also observed in our study, in which only one child above two years of age had pneumonia induced by RSV.

The high frequency of UTRI caused by RSV, the inexistence of cases with a fatal outcome and the number of cases of RSV infections in hospitalized children suggest that RSV was a frequent cause of mild to severe infection, but not usually a life-threatening one among children attended at PCPHO.

Our results support data indicating that RSV is one of the most important agents of ARI in childhood. The long epidemic period of RSV infections observed in Salvador can be helpful for the planning and implemetation of some preventive strategies. Longitudinal studies must be performed to confirm the results obtained in this shortterm study. Efficient strategies such as control of hospital infections by RSV, the use of antiviral therapy and a more rational use of antibiotics in viral ARI could be some of many benefits generated by longitudinal studies of the clinical and epidemiological aspects of RSV infections.

\section{REFERENCES}

Anderson LJ, Hierholzer JC, Tsou C, Hendry RM, Fernie BN, Stone Y, McIntosh K 1985. Antigenic characterization of respiratory syncytial virus strains with monoclonal antibodies. J Infect Dis 151: 626-633.

Avendaño LF, Larrañaga C, Palomino MA, Gaggero A, Montaldo G, Suarez M, Diaz A 1991. Community and hospital acquired respiratory syncytial virus infections in Chile. Pediatr Infect Dis J 10: 564-568.

Cane PA, Weber M, Sanneh M, Dackour R, Pringle CR, White H 1999. Molecular epidemiology of respiratory syncytial virus in the Gambia. Epidemiol Infect 122: 155-160.

Cintra OAL, Owe MA, Machado AA, Cerwi MC, Figueiredo LT, Rocha GM, Siqueira MM, Arruda E 2001. Occurrence and severity of infections caused by subgroup A and B respiratory syncytial virus in children in Southeast Brazil. J Med Virol 65: 408-412.

Checon RE, Siqueira MM, Lugon AK, Portes S, Dietze R 2002. Seasonal pattern of respiratory syncytial virus in a region with a tropical climate in Southeastern Brazil. Am Trop Med Hyg 67: 490-491.

Collins PL, McIntosh K, Chanock M 1996. Respiratory syncytial virus. In BN Fields, DM Knipe, PM Howley (eds), Virology, Philadelphia, p. 1313-1351.

Glezen WP, Paredes A, Allison JE, Raber LH, Frank AL 1981. Risk of respiratory syncytial virus infection for infants from low-income families in relationship to age, sex, ethnic group and maternal antibody level. J Pediatr 98: 708- 715.

Hendry RM, Tallis AL, Godfrey E, Anderson LJ, Fernie BF, McIntosh 1986. Concurrent circulation of antigenically distintic strains of respiratory syncytial virus during community outbreaks. J Infect Dis 153: 291-297.

Hierholzer JC, Tannock GA, Hierholtzer CM, Coombs RA, Kenneth, PA, Phillips PA, Gust ID 1994. Subgouping of respiratory syncytial virus strains from Australia and Papua New Guinea by biological and antigenic characteristics. Arch Virol 136: 133-147.

Imaz MS, Sequeira MD, Videla C, Veronessi I, Cociglio R, Zerbini E, Carballal G 2000. Clinical and epidemiologic characteristics of respiratory syncytial virus subgroups A and $\mathrm{B}$ infections in Santa Fe, Argentina. J Med Virol 61: 76-80.

Kong X, Shou H, Liu C, Jang Z 2001. Molecular epidemiology of respiratory siyncytial virus. Chinese Med J 114: 364368.

Loscertales MP, Roca A, Peret JV, Abacassamo F, Dos Santos F, Siatube M, Menéndez C, Greenwood BM, Saiz JC, Alonso PL 2002. Epidemiology and clinical presentation of respiratory syncytial virus infection in a rural area of Southern Mozambique. Pediatr Infec Dis J 21: 148-155.

Mello WA, Silva C 1992. Epidemiological aspects of RSV subgroups in Belém, Brazil. Boletin Latino-Americano 1: 8.

Mufson MA, Örvell C, Rafnar B, Morrby E 1985. Two distinct subtypes of human respiratory syncytial virus. J Gen Virol 66: 2111-2124.

Nascimento JP, Siqueira MM, Sutmoller F, Krawczuk MM, Farias V, Ferreira V, Rodrigues MJ 1991. Longitudinal study of acute respiratory diseases in Rio de Janeiro: occurrence of respiratory viruses during four consecutives years. Rev Inst Med Trop São Paulo 33: 287-296.

Parrot RH, Kim HW, Arrobio JO, Hodes DS, Murphy BR, Brandt CD, Chanock RM 1973. Epidemiology of respiratory syncytial virus infection in Washington DC II. Infection and disease with respect to age, immunologic status, race and sex. Am J Epidemiol 98: 289-300.

Roca A, Loscertales MP, Quintó L, Pérez-Brena P, Vaz N, Alonso PL, Saiz JC 2001. Genetic variability among group $\mathrm{A}$ and $\mathrm{B}$ respiratory syncytial viruses in Mozambique: idenfication of a new cluster of group B isolates 2001. J Gen Virol 82: 103-11. 
Russi JC, Delfraro A, Arbiza JR, Chiparelli H 1989. Antigenic characterization of respiratory syncytial virus associated with acute respiratory infection in Uruguayan children from 1985 to 1987. J Clin Microbiol 27: 1461-1466.

Siqueira MM, Nascimento JP, Anderson LJ 1991. Antigenic characterization of respiratory syncytial virus group A and B isolates in Rio de Janeiro, Brazil. J Clin Microbiol 29: 557-559.

Siqueira MM, Ferreira V, Nascimento JP 1986. RS virus diagnosis: comparison of isolation, immunofluorescence and enzyme immunoassay. Mem Inst Oswaldo Cruz 81: 225-232.

Straliotto SM, Nestor SM, Siqueira MM 2001. Respiratory syncytial virus group A and B in Porto Alegre, Brazil, from 1990 to 1995 and 1998. Mem Inst Oswaldo Cruz 96: 155158.

Sullender WM 2000. Respiratory syncytial virus genetic and antigenic diversity. Clin Microbiol Rev 13: 1-15.
Sutmoller F, Ferro ZPA, Asensi MD, Ferreira V, Mazzei IS, Cunha, BL 1995. Etiology of acute respiratory tract infections among children in a combined community and hospital study in Rio de Janeiro. Clin Infec Dis 20: 854-60. Vieira SE, Stewien KE, Queiroz DA, Durigon EL, Török TJ, Anderson LJ, Miyao CR, Hein N, Botosso VF, Pahl MM, Gilio AE, Ejzenberg B, Okay Y 2001. Clinical patterns and seasonal trends in respiratory syncytial virus hospitalizations in São Paulo, Brazil. Rev Inst Med Trop São Paulo 43: 125-131.

Weber MW, Dackour R, Usen S, Schineider G, Adegbola RA, Cane PA, Jaffar S, Milligan P, Greenwood BM, Whittle H, Mulholland K 1998b. The clinical spectrum of respiratory syncytial virus disease in the Gambia. Pediatric Infect Dis $J$ 17: 224-230.

Weber MW, Mulholland EK, Greenwood BM 1998a. Respiratory syncytial virus in developing countries. Trop Med and Internat Health 3: 268-280. 